University of Nebraska - Lincoln

DigitalCommons@University of Nebraska - Lincoln

Faculty Publications from the Harold W. Manter Laboratory of Parasitology

$5-1996$

\title{
A New Species of Acanthobothrium Van Beneden, 1849 (Eucestoda: Tetraphyllidea: Onchobothriidae) in Dasyatis longus Garman (Chondrichthyes: Myliobatiformes: Dasyatididae) from Chamela Bay, Jalisco, Mexico
}

Scott Monks

monks.scott@gmail.com

Daniel R. Brooks

University of Toronto,dnlbrooks@gmail.com

Gerardo Pérez-Ponce de León

Universidad Nacional Autonoma de Mexico, ppdleon@servidor.unam.mx

Follow this and additional works at: https://digitalcommons.unl.edu/parasitologyfacpubs

Part of the Parasitology Commons

Monks, Scott; Brooks, Daniel R.; and Pérez-Ponce de León, Gerardo, "A New Species of Acanthobothrium Van Beneden, 1849 (Eucestoda: Tetraphyllidea: Onchobothriidae) in Dasyatis longus Garman (Chondrichthyes: Myliobatiformes: Dasyatididae) from Chamela Bay, Jalisco, Mexico" (1996). Faculty Publications from the Harold W. Manter Laboratory of Parasitology. 281.

https://digitalcommons.unl.edu/parasitologyfacpubs/281

This Article is brought to you for free and open access by the Parasitology, Harold W. Manter Laboratory of at DigitalCommons@University of Nebraska - Lincoln. It has been accepted for inclusion in Faculty Publications from the Harold W. Manter Laboratory of Parasitology by an authorized administrator of DigitalCommons@University of Nebraska - Lincoln. 


\title{
A NEW SPECIES OF ACANTHOBOTHRIUM VAN BENEDEN, 1849 (EUCESTODA: TETRAPHYLLIDEA: ONCHOBOTHRIIDAE) IN DASYATIS LONGUS GARMAN (CHONDRICHTHYES: MYLIOBATIFORMES: DASYATIDIDAE) FROM CHAMELA BAY, JALISCO, MEXICO
}

\author{
Scott Monks, Daniel R. Brooks, and Gerardo Pérez Ponce de León* \\ Department of Zoology, University of Toronto, Toronto, Ontario, Canada M5S 1A1
}

\begin{abstract}
A new species of Acanthobothrium in Dasyatis longus from Chamela Bay, Jalisco, Mexico, is a member of a presumed clade of species diagnosed by being anapolytic or nearly so, having more than 100 testes per proglottis, with immature and mature proglottides wider than long to square, aspinose scolex, muscular bothridia fused to the scolex at their posterior ends, H- to V-shaped ovaries, relatively short symmetrical to asymmetrical ovarian arms that extend anteriorly to, or nearly to, the cirrus sac, and vitellaria arranged in fields rather than a single row of follicles. The new species most closely resembles Acanthobothrium terezae from the freshwater stingray Potamotrygon motoro in the following characters: bothridial hooks longer than $200 \mu \mathrm{m}$ with inner hooks having bent asymmetrical prongs, an average of 130-140 testes per proglottis, and shallow genital atria located posterior to midline of proglottis. The new species differs from $A$. terezae by having outer hooks approximately the same size and shape as the inner hooks, inner hooks averaging $230 \mu \mathrm{m}$ rather than $313 \mu \mathrm{m}$ in total length, and cirrus sacs averaging $255 \mu \mathrm{m}$ rather than $450 \mu \mathrm{m}$ in length. The new species is unique among all described species of Acanthobothrium by having a cleft in the posterior margin of each apical bothridial pad. The apparent close relationship of the new species to one inhabiting a Neotropical freshwater stingray provides support for the hypothesized Pacific marine ancestry of Neotropical freshwater stingrays and raises the possibility that the Neotropical freshwater stingrays may not be monophyletic.
\end{abstract}

One of the most species-rich genera of tetraphyllidean eucestodes is Acanthobothrium van Beneden, 1849. During the course of an inventory of the parasite fauna of fish from Chamela Bay, Jalisco State, Mexico, we collected numerous specimens of a new species of Acanthobothrium inhabiting Dasyatis longus Garman The new species adds to our understanding of the evolution of Neotropical freshwater stingrays (family Potamotrygonidae).

\section{MATERIALS AND METHODS}

Commercial fishermen captured specimens of Dasyatis longus with long lines 1-2 km from the shore of Chamela Bay, Jalisco State, Mexico $\left(19^{\circ} 31^{\prime} \mathrm{N}, 105^{\circ} 04^{\prime} \mathrm{E}\right)$. Cestodes were removed from the spiral valve of the host, killed with hot tap water, transferred immediately to AFA for 24-48 hr, then stored in 70\% ethanol. Specimens were stained either with Mayer's carmalum or Ehrlich's hematoxylin and mounted in Canada balsam for examination as whole mounts. Serial sections of proglottides were cut 7-10 $\mu \mathrm{m}$ thick, stained with Masson's trichrome, and mounted in Canada balsam for examination. Specimens were prepared for scanning electron microscopy by postfixation in $1 \%$ osmium tetroxide, and processed in Peldri II (Pelco International, Riverdale, California) prior to sputter coating with gold. Specimens were examined using a Hitachi S-2500 scanning electron microscope. Figures were drawn with the aid of a drawing tube. Measurements are in micrometers unless otherwise stated; for some traits, ranges are given, followed by, in parentheses, mean values \pm 1 standard deviation $(\bar{x}=$ mean; $\mathbf{n}=$ sample size). Hook measurements follow Euzet (1956) modified as follows: for each parameter, mean value \pm 1 standard deviation is given followed by, in parentheses, its range. CHIBUNAM refers to the Colleción Helminthológica del Instituto de Biología, Universidad Nacional Autónoma de Mexico, Mexico City, Mexico; UNSMHWML refers to the University of Nebraska State Museum, Harold W Manter Laboratory, Division of Parasitology, Lincoln, Nebraska, U.S.A.; MNHG INV refers

Received 10 July 1995; revised 18 December 1995; accepted 18 December 1995.

* Laboratorio de Helmintología, Instituto de Biologia, Universidad Nacional Autónoma de México, Ap. Postal 70-153 C.P. 04510, Mexico D.F., Mexico. to the Museum of Natural History, Geneva, Switzerland, Division of Invertebrates; FIOCRUZ Helm Col refers to the Coleçăo Helmintológica, FIOCRUZ, Instituto Oswaldo Cruz, Rio de Janeiro, Brasil.

\section{DESCRIPTION \\ Acanthobothrium cleofanus $\mathbf{n}$. sp. (Fig. 1A, B, D, E)}

Description (based on 40 specimens): Strobila acraspedote, anapolytic, 3.7-6.7 (5.0 $\pm 1.0, \mathrm{n}=10) \mathrm{cm}$ long; composed of 97-150 (120 \pm 15 , $\mathrm{n}=10)$ proglottides. Scolex 731-1,030 (919 $\pm 75 ; \mathrm{n}=39)$ wide, composed of 4 sessile triloculate bothridia; each bothridium with apical sucker and pad, armed with pair of bifid hooks. Bothridia with thick muscular walls; 477-719 (636 $\pm 51 ; n=40)$ long by $286-477(417 \pm$ $38, n=40$ ) wide. Locular wall dividing anterior and middle loculi relatively thick and muscular, between middle and posterior loculi relatively thin. Anterior loculus $127-235(172 \pm 26, n=40)$ long, middle loculus 70-140 (113 $\pm 17, n=40)$ long, posterior loculus 25-76 (54 \pm $15, n=40)$ long. Ratio of loculi lengths 1:0.6:0.3. Apical sucker 108$159(136 \pm 11, \mathrm{n}=40)$ in diameter; pads muscular, 232-331 (289 \pm $22, n=40$ ) wide. Posterior edge of apical muscular pads extending posteriorly over handles of hooks, divided in middle to form 2 curved extensions, 1 over each hook. Outer prongs of bothridial hooks shorter than inner prongs; inner prong of hooks twisted. Hook formula for external hooks $(n=40)$ :

$$
\frac{106 \pm 5(95-117) \quad 145 \pm 10(117-170) 57 \pm 6(47-69)}{227 \pm 13(198-258)} .
$$

Hook formula for internal hooks $(n=40)$ :

$$
\frac{105 \pm 7(88-117) \quad 146 \pm 9(121-164) 58 \pm 9(38-72)}{232 \pm 14(192-263)} .
$$

Cephalic peduncle unspined, $1,150-3,530(1,770 \pm 510, \mathrm{n}=39)$ long. Immature proglottides wider than long; terminal proglottides 1,050 $2,230(1,700 \pm 310, n=31)$ long by $331-750(539 \pm 115, n=29)$ wide. Testes 114-172 (140 $\pm 12, \mathrm{n}=38)$ in number, 32-64 (44 \pm 8 , $\mathrm{n}=37)$ in diameter; 43-64 (14 $\pm 2, \mathrm{n}=39)$ preporally, 6-11 $(8 \pm 1$, $\mathrm{n}=39)$ postporally, 19-33 $(26 \pm 3, \mathrm{n}=39)$ antiporally. Testis size and number greatly reduced or lacking in terminal proglottides. Cirrus sac slightly posterior to midproglottis, containing spined eversible cirrus; extending medially to mid-proglottis, curved posteriorly in terminal proglottides. Cirrus sac $134-337(255 \pm 49, \mathrm{n}=36)$ long, $127-235(170$ $\pm 26, \mathrm{n}=36$ ) wide. Cirrus $1,197 \mu \mathrm{m}$ long when extended, slightly 

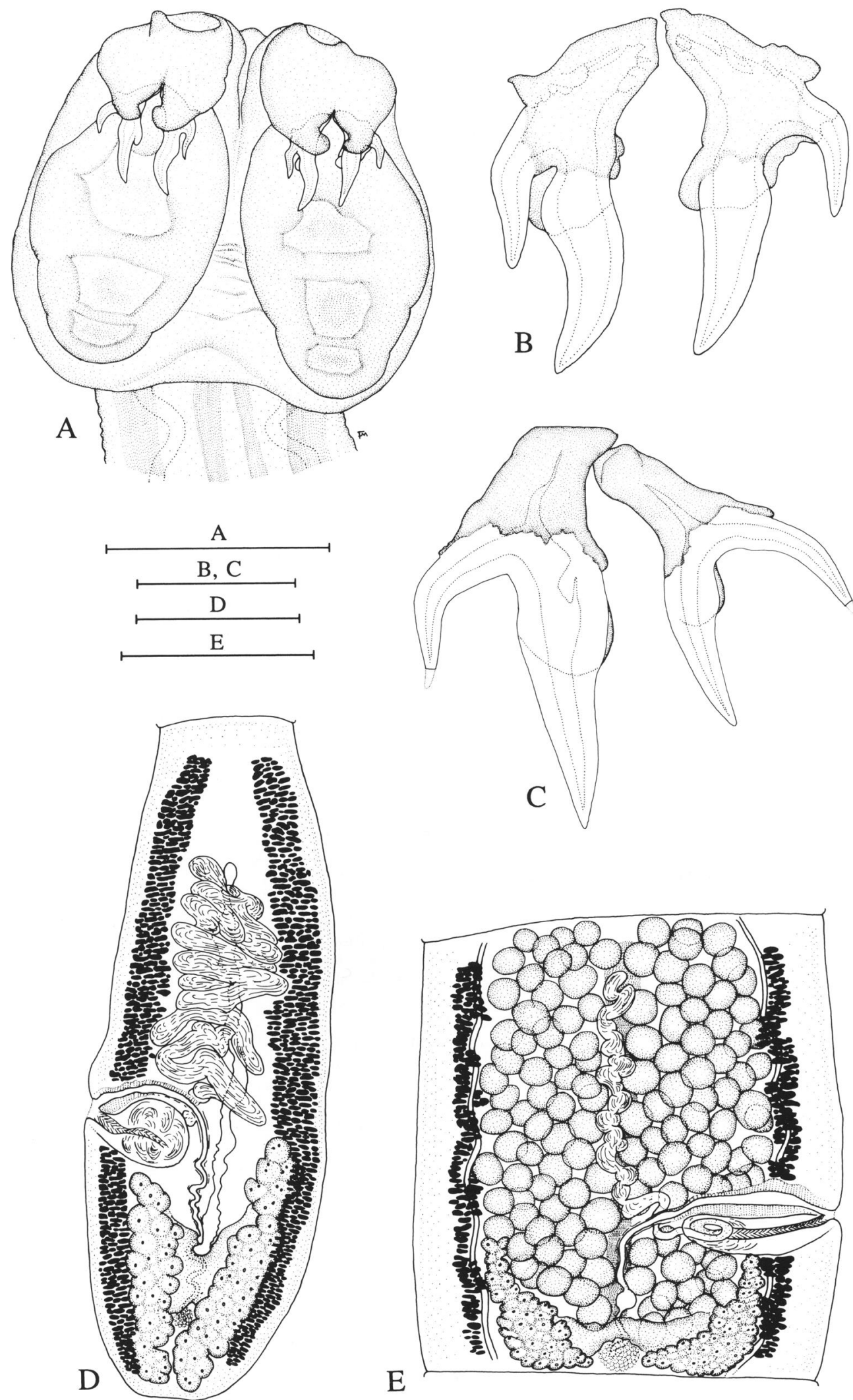

FIGURE 1. Acanthobothrium cleofanus n. sp. A. Scolex (scale bar $=500 \mu \mathrm{m})$. B. Enlargement of pair of bothridial hooks (scale bar $=100 \mu \mathrm{m})$. C. Acanthobothrium terezae, enlargement of pair of bothridial hooks (scale bar $=100 \mu \mathrm{m})$. Acanthobothrium cleofanus $\mathrm{n}$. $\mathrm{sp}$. D. Terminal attached proglottis $($ scale bar $=500 \mu \mathrm{m})$. E. Mature nonterminal attached proglottis (scale bar $=300 \mu \mathrm{m})$. In B and C, inner hooks are on the left, outer hooks on the right. 
swollen at base; spines thin, averaging 13 long basally, 3 long at tip. Vas deferens coiled, extending anteriorly from cirrus sac to near anterior end of proglottis, filled with sperm in terminal proglottides. Genital atrium shallow. Genital pore located $54-65 \%(60 \pm 3 \%, n=36)$ of total length of proglottis from anterior end, irregularly alternating. Vagina anterior to cirrus sac, vaginal wall glandular, vaginal sphincter present as a muscular thickening of the distal portion of the vagina. Vagina looping posteriorly on aporal side of midline, slightly coiled in terminal proglottides. Ovary near posterior end of proglottis, X-shaped in cross section, with foliose lobes; shape in frontal view changing as proglottides mature: nearly U-shaped in immature proglottides, $\mathrm{H}$-shaped in mature proglottides (Fig. 1E), and inverted A- or V-shaped in terminal proglottides (Fig. 1D). Ovary 26-51 (44 $\pm 7, \mathbf{n}=9)$ wide at isthmus; arms unequal in length. Aporal arm 445-840 (616 $\pm 99, \mathrm{n}=32)$ long, extending to anterior margin of cirrus sac; poral arm 299-738 (501 \pm 103 , $n=32$ ) long, extending to level of posterior margin of cirrus sac. Mehlis' gland immediately posterior to ovarian isthmus; seminal receptacle at level of or slightly anterior to isthmus. Vitelline follicles elongate oval in shape, 13-32 (19 $\pm 6, n=34)$ wide, $35-69(51 \pm 10, n=34)$ long, extending as narrow bands on each side of proglottis. Uterus saccate, narrowly elongate in terminal attached proglottides, expanded laterally filling available preovarian space in detached proglottides. Eggs not observed.

\section{Taxonomic summary}

Host: Dasyatis longus Garman (Chondrichthyes: Myliobatiformes: Dasyatididae).

Site of infection: Spiral valve.

Locality: Chamela Bay, Jalisco, México $\left(19^{\circ} 31^{\prime} \mathrm{N}, 105^{\circ} 04^{\prime} \mathrm{E}\right)$; June 1994.

Holotype: CHIBUNAM no. 2670.

Paratypes: CHIBUNAM no. 2671 (25 specimens); MNHG INV 38576 (5 specimens); MNHG INV 38576 (5 specimens); UNSMHWML 38576 (5 specimens).

Etymology: The specific epithet, meaning "cleft," refers to the distinct structure of the apical pad, which is diagnostic for this species.

\section{Remarks}

Acanthobothrium van Beneden, 1849 currently contains more than 80 nominal species. Within that collection, there is a group characterized by the following features: (1) strobilae anapolytic or nearly so; (2) more than 100 proglottides per strobila; (3) bothridia fused to the scolex at their posterior ends; (4) bothridial hooks usually large, more than 150 $\mu \mathrm{m}$ long, with prongs short relative to the handle, giving them a stumpy appearance or with asymmetrical prongs, the outer prong being much shorter than the inner one; (5) more than 100 testes per proglottis, usually averaging 150 or more; (6) all except terminal proglottides wider than long or square; (7) foliose ovarian arms, usually flat or low H- to V-shaped, extending anteriorly to the level of the cirrus sac, sometimes with asymmetrical arms; (8) genital pores indistinct and located at or posterior to midline of proglottis; and (9) vitellaria in fields rather than single rows of follicles, especially in the oldest proglottides. These traits are lacking or relatively rare in other tetraphyllideans, so we consider them synapomorphies, diagnosing those species as a clade within the genus.

Within the above clade are 13 species that exhibit bothridial hooks with asymmetrical prongs. This trait is highly unusual among members of Acanthobothrium and is restricted to the species within the clade diagnosed in the preceding paragraph. Therefore, we consider this trait a synapomorphy diagnosing a clade containing $A$. cleofanus, Acanthobothrium coronatum (Rudolphi, 1819) van Beneden, 1849 (inhabiting Scyliorhinus stellaris (Linnaeus, 1758) from the Mediterranean Sea), Acanthobothrium crassicolle Wedl, 1855 (inhabiting Dasyatis pastinaca (Linnaeus, 1758) from the northeast Atlantic Ocean and Mediterranean Sea), Acanthobothrium herdmani Southwell, 1912 (inhabiting Dasyatis kuhli (Müller and Henle, 1841) from Ceylon, Acanthobothrium ijimae Yoshida, 1917 (inhabiting Dasyatis akajei Lindberg and Legeza, 1959 from the western Pacific Ocean, Ceylon, and the northern Atlantic Ocean), Acanthobothrium grandiceps Yamaguti, 1952 (inhabiting D. akajei and Dasyatis zugei (Müller and Henle, 1841) from the East China Sea), Acanthobothrium latum Yamaguti, 1952 (inhabiting D. akajei from the Sea of Ariake, Japan), Acanthobothrium micracanthum Yamaguti, 1952 (inhabiting D. akajei, D. zugei, and Pteroplatea micrura (Müller and Henle, 1841) from the East China Sea), Acanthobothrium rhynchobatidis Subhapradha, 1955 (inhabiting Rhynchobatus djiddensis (Forsskål, 1775) from India), Acanthobothrium robustum Alexander, 1953 (inhabiting Rhinobatos productus Girard, 1855 from California), Acanthobothrium septentrionale Baer and Euzet, 1962 (inhabiting Raja sp. from the North Sea), Acanthobothrium terezae Rêgo and Dias, 1974 (inhabiting Paratrygon aerieba (Müller and Henle, 1841) from Brazil), and possibly Acanthobothrium intermedium Perrenoud, 1931 (inhabiting D. pastinaca from New Zealand) (see Euzet, 1956; Goldstein, 1967; Williams, 1969; Schmidt, 1986).

Among described species of Acanthobothrium, A. cleofanus is distinctive by virtue of possessing a distinct medial cleft in each apical pad (Figs. 1A, 2A, B). Acanthobothrium robustum, A. ijimae, and $A$. septentrionale were described as having 2, 2, and 3 apical suckers, respectively, whereas $A$. cleofanus has a single sucker only. Acanthobothrium cleofanus also differs from these 3 species by having bothridial hooks averaging $230 \mu \mathrm{m}$ rather than approximately $150 \mu \mathrm{m}$ in total length, smaller bothridia than $A$. ijimae and $A$. septentrionale, and larger bothridia than $A$. robustum. It also has an average of 140 rather than 100 115 testes per proglottis, cirrus sacs reaching to proglottis rather than only to the middle of the poral testicular field, and genital pores more posterior to mid-proglottis. The new species is similar to $A$. coronatum in average strobilar length, possession of bothridial hooks with relatively short inner prongs averaging $220-230 \mu \mathrm{m}$ in total length, vaginal sphincter, shallow genital atrium, and lack of velum, but differs in other respects. The bothridia of $A$. coronatum tend to be larger than those of $A$. cleofanus, although the range of bothridial length in the 2 species overlaps slightly, being 477-719 for $A$. cleofanus and 700-900 for $A$. coronatum. Acanthobothrium cleofanus has larger apical accessory suckers than $A$. coronatum (108-159 vs. 80-90 $\mu \mathrm{m}$ ), fewer proglottides (97150 vs. $200-350$ ), and a higher average number of testes (140 vs. 106). The new species has generally smaller cirrus sacs than $A$. coronatum ( $255 \mu \mathrm{m}$ long by $170 \mu \mathrm{m}$ wide vs. $480 \mu \mathrm{m}$ long by $280 \mu \mathrm{m}$ wide), which curve slightly to the posterior and extend medially to the midline of the proglottis. By contrast, the cirrus sacs of $A$. coronatum are straight and do not reach the midline of the proglottis. The unequal ovarian arms of $A$. cleofanus extend to the level of the cirrus sac, whereas the equal arms of $A$. coronatum extend only about halfway to the cirrus sac. The bothridia of the new species are completely fused to the scolex (Fig. 1A), whereas those of $A$. coronatum are only slightly attached at the posterior margins (Euzet, 1956). Acanthobothrium cleofanus is similar to $A$. crassicolle, A. herdmani, A. intermedium, A. latum, A. micracanthum, and $A$. rhynchobatidis by having $100-172$ testes per proglottis, mid- to postmarginal genital pores, unequal ovarian arms, and poral ovarian arms extending anteriorly to the posterior margin of the cirrus sac. The new species differs from these 6 latter species by having shorter strobilae (averaging $50 \mathrm{~mm}$ vs. $70-169 \mathrm{~mm}$ in the other 6 species), fewer proglottides per strobila (averaging 120 vs. 400 or more in other 6 species), and having cirrus sacs curving posteriorly in terminal proglottides rather than extending medially only. The cirrus sacs of $A$. crassicolle, $A$. herdmani, $A$. intermedium, $A$. latum, and $A$. micracanthum do not extend medially to the midline of the proglottis, whereas, in $A$. cleofanus, they do. Acanthobothrium intermedium was originally described as having a spined peduncle (Perrenoud, 1931; Euzet, 1956) which differs from those of $A$. cleofanus and all other species discussed above. The original specimens of $A$. intermedium have been lost (Williams, 1969) and synonymy with $A$. crassicolle is generally accepted (Williams, 1969; Schmidt, 1986), so it is possible that the report of spinose peduncles for the specimens described as $A$. intermedium was in error.

Acanthobothrium cleofanus appears most similar to A. terezae. We obtained 2 paratypes of $A$. terezae (FIOCRUZ Helm Col nos. 31.215ab) for detailed comparison with our material. Specimens of both $A$ cleofanus and $A$. terezae are anapolytic, acraspedote, and exhibit thickwalled, muscular bothridia attached at the base to a thick peduncle. They both have robust bothridial hooks, foliose U- to V-shaped ovaries, and vitellaria distributed as a narrow band of follicles extending the length of the proglottis. Both species exhibit a similar average number of testes, 140 for $A$. cleofanus and 130 for $A$. terezae; furthermore, in both species approximately $50 \%$ of the testes occur in the aporal field. In the other species discussed above, the aporal field contains an average of $57 \%$ of the testes in a given proglottis. The ratio of locular lengths 
for $A$. cleofanus is $1: 0.6: 0.5$, whereas for $A$. terezae it is approximately 1:0.6:0.8 (the excessively flattened condition of the paratypes of $\boldsymbol{A}$. terezae did not permit precise measurements). In the new species, the apical sucker averages $136 \mu \mathrm{m}$ in diameter; precise measurements of the apical suckers of the paratypes of $A$. terezae could not be obtained, but in the original description, Rêgo and Dias (1976) state a diameter of $87 \mu \mathrm{m}$. Strobilae of $A$. cleofanus are shorter than those of $A$. terezae (50 vs. $99 \mathrm{~mm}$ ), largely because they have fewer proglottides (120 vs. 230).

Acanthobothrium cleofanus further differs from $A$. terezae by having inner and outer bothridial hooks that are virtually identical in shape (Fig. 1B), whereas those of $A$. terezae differ both in size and shape (Fig. 1C). The shape of the outer hooks of $A$. terezae are typical of most species of Acanthobothrium, and the shape of the inner hooks is highly similar to both hooks of $A$. cleofanus. The condition exhibited by $A$. terezae may thus be an evolutionary transition from the condition exhibited by most members of the genus to that found in $A$. cleofanus. The hooks on each bothridium of $A$. cleofanus are approximately equal in total length, a condition common to most members of the genus. In $A$. terezae, by contrast, the total length for the inner hooks of $A$. terezae (average $313 \mu \mathrm{m}$ ) is substantially greater than that of the outer hooks (average $226 \mu \mathrm{m}$ ) or the hooks of $A$. cleofanus (average $230 \mu \mathrm{m}$ ). This appears to be an autapomorphic trait for A. terezae. Finally, as mentioned above, $A$. cleofanus differs from $A$. terezae and all other reported species of Acanthobothrium by having a cleft in the posterior margin muscular apical pads of each bothridium (Figs. 1A, 2A, B). If $A$. terezae is the sister species of $A$. cleofanus, it might exhibit a similar structure, but we could not confirm the details of the structure of the bothridial apical pads of $A$. terezae due to the excessively flattened nature of the scoleces of the paratypes we examined. This character is readily visible using scanning electron microscopy and should be re-evaluated by examination of additional specimens of $A$. terezae.

\section{DISCUSSION}

If $A$. cleofanus is the sister species of $A$. terezae, as suggested above, it offers 2 significant pieces of information about the evolution the helminth fauna of Neotropical freshwater stingrays (family Potamotrygonidae). First, A. cleofanus provides further corroboration for the hypothesis that potamotrygonids have a Pacific marine ancestry (Brooks et al., 1981; Brooks and Deardorff, 1988; Brooks, 1992, 1995; Brooks and McLennan, 1991, 1993), because it occurs in a marine host inhabiting the eastern Pacific coast. Second, A. cleofanus offers at least partial refutation of the hypothesis that potamotrygonids are derived from a urolophid ancestor (Brooks et al., 1981). This study presents the first evidence that $A$. terezae, which inhabits $P O$ tamotrygon motoro (Natterer, 1841) and Paratrygon aerieba, is not the sister species of the clade containing Acanthobothrium quinonesi Mayes, Brooks, and Thorson, 1978, Acanthobothrium regoi Brooks, 1981, and Acanthobothrium amazonensis Mayes, Brooks, and Thorson, 1978, all of which inhabit species of $\mathrm{PO}_{\mathrm{O}}$ tamotrygon. The latter 3 species are highly similar to species of Acanthobothrium inhabiting species of Urolophus (including Urobatis of some authors), suggesting a relationship between Urolophus and Potamotrygon. The putative sister species relationship between $A$. cleofanus, which inhabits a member of Dasyatis, and A. terezae suggests a relationship between Dasyatis and the monotypic Paratrygon. In fact, none of the species of the putative clade of Acanthobothrium species of which A. ter-

FIGURE 2. Acanthobothrium cleofanus n. sp., scanning electron photomicrographs emphasizing structure of bothridial apical pads. A. Scolex (scale bar $=300 \mu \mathrm{m})$. B. Enlargement of bothridial apical pad (scale bar $=50 \mu \mathrm{m})$.
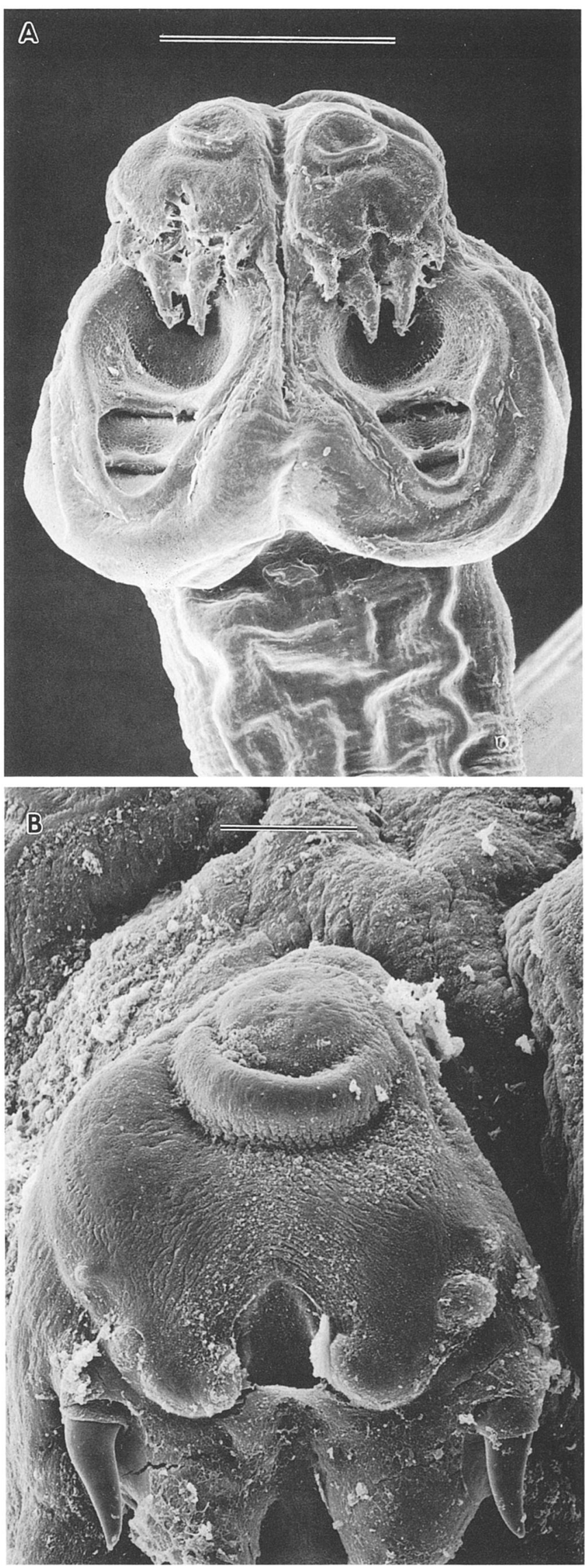
ezae and $A$. cleofanus are members inhabit urolophid stingrays. This provides a strong indication that the helminth fauna of potamotrygonids is not monophyletic, suggesting 1 of 2 possibilities. First, it is possible that the helminth fauna of potamotrygonids represents a mixture of resident and colonizer clades, involving parasites from urolophid and dasyatidid hosts. In this case, current phylogenetic hypotheses indicating closer relationships between dasyatidids and potamotrygonids than between urolophids and potamotrygonids would suggest that the colonizers are from urolophids. The second possibility is that the helminths of freshwater stingrays represent 2 resident faunas, suggesting that potamotrygonids themselves are not monophyletic, perhaps with Paratrygon Duméril, 1865 (and possibly Plesiotrygon Rosa, Castello and Thorson, 1987, for which no parasites are as yet reported) being most closely related to dasyatidids, and Potamotrygon Garman, 1877 being most closely related to urolophids. In this case, the current high levels of homoplasy depicted in phylogenetic studies of stingray taxa might result from the polyphyletic status of the Potamotrygonidae. In either case, additional studies of helminths inhabiting marine stingrays along the eastern Pacific coast, those inhabiting species of Potamotrygon, and especially of those inhabiting the monotypic Plesiotrygon and Paratrygon, will be necessary to resolve the original source of each of the parasite groups. Furthermore, new phylogenetic analyses of stingray relationships considering the possibility that potamotrygonids are not monophyletic should be investigated.

\section{ACKNOWLEDGMENTS}

We gratefully acknowledge the help of Felipe Noguera, Chief of the Estación de Biologia Chamela, for assistance in allowing us access to station facilities; the estimable Don Toño, who collected the fish examined in this study; and Deborah McLennan, University of Toronto, who helped collect parasite specimens. We thank Fernando Marques for his preparation of the illustrations and Dely Noronha, Instituto Oswaldo Cruz, for loan of the specimens of $A$. terezae. This study was funded by operating grants A7696 from the Natural Sciences and Engineering Council (NSERC) of Canada to D.R.B. and IN201593 from the Programa de Apoyo a Proyectos de Investigación e Inovación Tecnológica-UNAM to G.P.P.dL.

\section{LITERATURE CITED}

BROOKs, D. R. 1992. Origins and diversification of Neotropical freshwater stingrays (Potamotrygonidae): Parasitological evidence. Journal of Parasitology 78: 588-595.

- 1995. Neotropical freshwater stingrays and their parasites: A tale of an ocean and a river long ago. Journal of Aquariculture and Aquatic Science (in press).

, AND T. L. DEARDORFF. 1988. Rhinebothrium devaneyi $\mathrm{n} . \mathrm{sp}$. (Eucestoda: Tetraphyllidea) and Echinocephalus overstreeti Deardorff and Ko, 1983 (Nematoda: Gnathostomatidae) in a thorny back ray, Urogymnus asperrimus, from Enewetak Atoll, with phylogenetic analysis of both species groups. Journal of Parasitology 74: $459-465$.

, M. A. MAYEs, AND T. B. Thorson. 1981. Systematic review of cestodes infecting freshwater stingrays (Chondrichthyes: Potamotrygonidae) including four new species from Venezuela. Proceedings of the Helminthological Society of Washington 48: 43-64. , AND D. A. Mclennan. 1991. Phylogeny, ecology, and behavior: A research program in comparative biology. University of Chicago Press, Chicago, Illinois, $434 \mathrm{p}$.

$\longrightarrow$ AND $\longrightarrow$. 1993. Parascript: Parasites and the language of evolution. Smithsonian Institution Press, Washington, D.C., 429 p.

EUZET, L. 1956. Recherches sur les cestodes tétraphyllides des sélaciens des côtes de France. Doctorat ès Sciences Naturelles. University of Montpellier, Montpellier, France, 263 p.

Goldsten, R. J. 1967. The genus Acanthobothrium van Beneden, 1849 (Cestoda: Tetraphyllidea). Journal of Parasitology 53: 455483.

Perrenoud, N. 1931. Recherches anatomiques et histologiques sur quelques cestodes de sélaciens. Revue Suisse de Zoologie 38: 469555.

RÊGo, A. A., AND A. P. L. DiAs. 1976. Estudos de cestóides de peixes do Brasil. 3. Nota: Cestóides de raias fluviais Paratrygonidae. Revista Brasileira de Biología 36: 941-956.

SCHMIDT, G. D. 1986. CRC handbook of tapeworm identification. CRC Press, Inc., Boca Raton, Florida, 675 p.

Williams, H. H. 1969. The genus Acanthobothrium van Beneden 1849 (Cestoda: Tetraphyllidea). Nytt Magasin for Zoologi 17: 1-56. 